\title{
Komparasi Pemahaman Konsep Siswa yang Diajar dengan Metode Mind Mapping dan Metode Guided Note Taking pada Kelas VIII SMP
}

\author{
Ishaq Munajah $^{1, a)}$, Ilham Minggi, ${ }^{1, b)}$ dan Ahmad Talib ${ }^{1, c)}$ \\ ${ }^{1}$ Jurusan Matematika FMIPA Universitas Negeri Makassar \\ a) ishaqmunajah00@gmail.com \\ b) ilhamminggi@gmail.com \\ c) ahmad.talib@unm.ac.id
}

\begin{abstract}
Abstrak. Penelitian ini adalah penelitian eksperimen yang melibatkan dua kelompok yang diberi perlakuan. Penelitian ini bertujuan untuk mengetahui perbedaan pemahaman konsep matematika antara siswa yang diajarkan menggunakan metode Mind Mapping dan metode Guided Note Taking. Sampel penelitian ini terdiri dari dua kelas yang dipilih dengan menggunakan teknik cluster random sampling. Pengumpulan data dilakukan dengan menggunakan instrumen lembar observasi dan tes pemahaman konsep, dan. Data yang terkumpul dianalisis secara deskriptif dan inferensial. Hasil penelitian menunjukkan bahwa terdapat perbedaan signifikan antara peningkatan pemahaman konsep matematika siswa yang diajar dengan metode pembelajaran Mind Mapping dan siswa yang diajar dengan menggunakan metode pembelajaran Guided Note Taking pada kelas VIII.
\end{abstract}

Kata Kunci: Mind Mapping, Guided Note Taking, Instrumen Tes Pemahaman Konsep, Lembar Observasi, dan Pemahaman Konsep

Abstract. This study was an experimental study involving two treated groups. This study aims to find out a differences in understanding of mathematical concepts between students taught using the Mind Mapping method and the Guided Note Taking method. The study sample consisted of two classes selected using the cluster random sampling technique. Data collection is done by using observation sheets and concept understanding test instruments. Data collected was analyzed descriptively and inferentially. The results showed that there are significant differences between increasing understanding of mathematical concepts of students taught by Mind Mapping learning methods and students taught using Guided Note Taking learning methods in class VIII.

Keyword: Mind Mapping, Guided Note Taking, Concept Understanding Test Instruments, Observation Sheets and Concept Understanding.

\section{PENDAHULUAN}

Masalah pokok dalam pembelajaran matematika pada pendidikan formal (sekolah) dewasa ini adalah masih rendahnya pemahaman konsep matematika siswa. Pemahaman konsep matematika memiliki peranan penting dalam pembelajaran terkhusus dalam pembelajaran matematika. Apalagi materi pelajaran matematika yang bersifat hirarki, dimana konsep-konsep matematika tersebut saling berkaitan.

Untuk mencapai pemahaman konsep dalam matematika bukanlah suatu hal yang mudah, sebab pemahaman konsep matematika oleh setiap siswa cenderung berbeda. Setiap siswa mempunyai 
kemampuan yang berbeda dalam memahami konsep-konsep matematika. Namun, upaya untuk meningkatkan pemahaman konsep matematika siswa harus dilakukan demi keberhasilan pembelajaran matematika siswa. Dalam hal ini, perlu dirancang suatu pembelajaran yang membiasakan peserta didik untuk mengkonstruksi sendiri pengetahuannya, sehingga peserta didik lebih memahami konsep/materi yang diajarkan. Salah satu cara yang dapat dilakukan untuk membiasakan peserta didik mengkontruksi sendiri pengetahuannya dengan cara melaksanakan model pembelajaran yang relevan untuk diterapkan oleh guru di sekolah/kelas (Heryani \& Rustina, 2016).

Pemahaman konsep merupakan kompetensi yang ditunjukkan siswa dalam memahami konsep dan dalam melakukan prosedur (algoritma) secara luwes, akurat, efisien, dan tepat (Depdiknas, 2003). Suherman (2003) menyatakan bahwa rendahnya pemahaman konsep matematika siswa disebabkan karena siswa kurang aktif dalam proses pembelajaran. Oleh karena itu, Memahami konsep-konsep matematika perlu memperhatikan konsep-konsep sebelumnya. Matematika tersusun secara hirarki yang satu sama lainnya berkaitan dengan erat. Konsep lanjutan tidak mungkin dapat di pahami sebelum memahami dengan baik konsep sebelumnya yang menjadi persyaratannya. Ini berarti matematika harus bertahap dan berurutan secara sistematis serta di dasarkan pada pengalaman belajar yang lalu. Seseorang akan sangat mudah mempelajari konsep-konsep matematika yang baru, bila di dasarkan kepada apa yang telah diketahui sebelumnya

Metode pembelajaran merupakan suatu cara membelajarkan peserta didik agar tercapainya tujuan pembelajaran. Pemilihan metode pembelajaran yang tepat dalam proses pembelajaran akan memudahkan siswa dalam mengkonstruksi sendiri pengetahuannya, sehingga konsepkonsep matematika yang diberikan dapat dengan mudah dipahami. Metode yang dapat digunakan untuk menyampaikan konsep dengan baik, terstruktur, menarik, serta dapat meningkatkan ingatan dan pemahaman konsep siswa dengan melejitkan potensi otak kanan yaitu metode pembelajaran Mind Mapping dan metode pembelajaran Guided Note Taking.

Mind Map membantu kita untuk memetakan apa yang kita pikirkan, apa yang kita ingin ingat dengan baik (Herdin, 2017). Karena Mind Map seperti gambar dari pikiran kita, apa yang kita pikirkan, terjemahan dari linear notes atau terhadap sesuatu yang kita pikirkan agar kita dapat mudah mengingatnya.Oleh karena itu, pembelajaran dengan metode Mind Mapping akan menuntun siswa dalam menguasai dan memahami konsep materi yang dipelajari. Metode Mind Mapping adalah metode yang diperkenalkan oleh Tony Buzan pada awal tahun 1970-an, metode ini mengharuskan siswa untuk dapat menemukan dan menuliskan setiap informasi-informasi penting materi yang di pelajari secara menyeluruh dalam satu peta pikiran secara utuh (Buzan, 2012). Beberapa penelitian telah mengkaji tentang Metode pembelajaran Mind Mapping (Utami, 2016; Nurlina, 2014). Penelitian tersebut menunjukkan bahwa penerapan metode Mind Mapping dapat meningkatkan kemampuan pemahaman konsep matematis siswa.

Metode pembelajaran Guide Note Taking adalah metode pembelajaran yang menggunakan suatu bagan, skema (handout) sebagai media yang dapat membantu siswa dalam membuat catatan ketika seorang guru sedang menyampaikan pelajaran dengan metode ceramah (Ambarwatik, 2012). Sehingga metode ini ampuh untuk meningkatkan pemahaman konsep siswa dengan memfokuskan perhatian siswa pada handout yang disajikan.

Metode Guide Note Taking dikembangkan agar metode ceramah yang dikembangkan guru mendapat perhatian siswa (Suprijono, 2014). Metode pembelajaran ini memungkinkan siswa belajar lebih aktif, karena memberikan kesempatan mengembangkan diri, fokus pada handout dan materi ceramah serta diharapkan mampu memecahkan masalah sendiri dengan menemukan (discovery) dan bekerja sendiri. Beberapa penelitian telah mengkaji tentang metode pembelajaran Guided Note Taking (Sulistia, 2012; Munajah, 2015). Penelitian tersebut menunjukkan bahwa penerapan metode Guided Note Taking dapat meningkatkan kemampuan pemahaman konsep matematis siswa 
Kedua metode yakni metode Mind Mapping dan metode Guided Note Taking memiliki kelebihan mengarahkan siswa agar lebih mudah memahami konsep dari materi yang diajarkan. Metode Mind Mapping mengembangkan cara belajar siswa dengan menyajikan materi berupa peta konsep yang akan mendorong potensi otak kanan siswa untuk lebih aktif, karena materi disajikan dengan menarik, sedangkan metode pembelajaran Guided Note Taking mampu mengembangkan kemampuan dan pemahaman konsep siswa dengan memfokuskan siswa pada modul/handout yang diberikan.

Penelitian ini mengkaji tentang komparasi pemahaman konsep siswa yang diajar dengan metode Mind Mapping dan metode Guided Note Taking pada pembelajaran matematika. Adapun tujuan penelitian ini adalah untuk mengetahui ada atau tidak ada perbedaan pemahaman konsep dan perbedaan peningkatan pemahaman konsep matematika siswa yang diajarkan menggunakan metode Mind Mapping dan metode Guided Note Taking.

\section{KAJIAN PUSTAKA}

\section{Metode Pembelajaran Mind Mapping}

Metode Mind Mapping adalah metode yang diperkenalkan oleh Tony Buzan pada awal tahun 1970-an, metode ini mengharuskan siswa untuk dapat menemukan dan menuliskan setiap informasi-informasi penting materi yang di pelajari secara menyeluruh dalam satu peta pikiran secara utuh (Buzan, 2012). metode Mind Mapping merupakan suatu metode pembelajaran yang sangat baik digunakan oleh guru untuk meningkatkan daya kreativitas siswa melalui kebebasan berimajinasi. Oleh karena itu, pembelajaran dengan metode Mind Mapping akan menuntun siswa dalam menguasai dan memahami konsep materi yang dipelajari.

Mind Map membantu kita untuk memetakan apa yang kita pikirkan, dan apa yang kita ingin ingat dengan baik (Herdin, 2017). Karena Mind Map seperti gambar dari pikiran kita, apa yang kita pikirkan, terjemahan dari linear notes atau terhadap sesuatu yang kita pikirkan agar kita dapat mudah mengingatnya. Mind Mapping merupakan metode pembelajaran yang membangun sebuah peta pikiran yang menarik dalam penyajiannya sehingga efektif untuk dijadikan metode dalam pembelajaran untuk meningkatkan pemahaman konsep peserta didik akan tetapi membutuhkan pengajar yang terampil dalam aplikasinya.

Menurut Buzan (2012) bahwa ada tujuh langkah untuk membuat Mind Map (peta pikiran). Tujuh langkah tersebut adalah sebagai berikut:

1. Memulai dari bagiapn tengah kertas kosong yang sisi panjangnya diletakkan mendatar.

2. Menggunakan gambar atau foto untuk ide sentral.

3. Menggunakan warna yang menarik.

4. Menghubungkan cabang-cabang utama ke gambar pusat dan hubungkan cabang-cabang tingkat dua dan tingkat tiga ke tingkat satu dan dua dan seterusnya.

5. Membuat garis hubung yang melengkung, bukan garis lurus.

6. Menggunakan satu kata kunci untuk setiap garis.

7. Menggunakan gambar

Beberapa penelitian telah mengkaji terkait metode pembelajaran Mind Mapping. Utami (2016) meneliti tentang penerapan metode Mind Mapping untuk meningkatkan kemampuan pemahaman konsep matematis siswa. Penelitian ini menunjukkan bahwa metode Mind Mapping mampu meningkatkan kemampuan pemahaman konsep matematis siswa dibandingkan menggunakan metode pembelajaran konvensional.

Nurlina (2014) meneliti tentang evektivitas pembelajaran quantum dengan menggunakan teknik Mind Mapping dalam pembelajaran matematika. Penelitian ini menunjukkan bahwa Teknik Mind Mapping efektif diterapkan dalam pembelajaran matematika. 


\section{Metode Pembelajaran Guided Note Taking}

Metode pembelajaran Guide Note Taking atau catatan terbimbing adalah metode pembelajaran yang menggunakan suatu bagan, skema (handout) sebagai media yang dapat membantu siswa dalam membuat catatan ketika seorang guru sedang menyampaikan pelajaran dengan metode ceramah (Ambarwatik, 2012).

Menurut Silberman (1996) Langkah-langkah dalam pelaksanaan metode Guided Note Taking yaitu:

1. Persiapkan sebuah handout yang menyimpulkan poin-poin penting dari sebuah pelajaran yang disampaikan dengan ceramah yang anda berikan.

2. Sebagai ganti memberikan teks yang lengkap, tinggalkan bagian-bagian teks itu kosong.

3. Bagikan Handout kepada peserta didik. Jelaskan bahwa Anda telah membuat blangkoblangko itu untuk membuat mereka mendengarkan secara aktif pelajaran yang disampaikan dengan ceramah.

Beberapa penelitian telah mengkaji tentang metode pembelajaran Guided Note Taking. Sulistia (2012) mengkaji tentang penerapan metode pembelajaran guided note taking untuk meningkatkan pemahaman konsep matematika. Penelitian ini menunjukkan nilai hasil tes evaluasi siswa telah memenuhi kriteria keberhasilan yaitu 75\% dari siswa telah memperoleh nilai $\geq 70$. Hal ini menunjukkan bahwa terjadi peningkatan pemahaman konsep matematika siswa pada pokok bahasan kesebangunan. Munajah (2015) mengkaji tentang efektivitas pembelajaran matematika melalui metode Guided Note Taking pada siswa kelas VII. Hasilnya menunjukkan bahwa metode Guided Note Taking pada pokok bahasan Phytagoras efektif diterapkan berdasarkan kriteria keefektifan pembelajaran.

\section{METODE PENELITIAN}

Penelitian ini adalah penelitian eksperimen semu (Quasi Experiment) yang melibatkan dua kelompok. Penelitian ini dilaksanakan di SMP kelas VIII. Sampel dalam penelitian ini terdiri dari 2 kelas, yaitu kelas eksperimen 1 sebanyak 24 siswa yang diajarkan dengan menggunakan metode pembelajaran Mind Mapping dan kelas eksperimen 2 sebanyak 23 siswa yang diajarkan dengan menggunakan metode pembelajaran Guided Note Taking. Variabel dalam penelitian ini ada dua jenis, yakni variabel bebas dan variabel terikat. Variabel bebas dalam penelitian ini adalah metode pembelajaran yang terdiri atas metode Mind Mapping dan metode Guided Note Taking, sedangkan pemahaman konsep bangun ruang siswa sebagai variabel terikat.

Teknik pengumpulan data yang dilakukan adalah observasi dan tes. Observasi dilakukan untuk mengetahui seberapa baik keterlaksanaan metode saat pembelajaraan berlangsung. Tes digunakan untuk memperoleh data mengenai penguasaan pemahaman konsep matematika siswa setelah mengalami proses pembelajaran dengan menggunakan metode Mind Mapping dan Guide Note Taking. Instrumen yang dikembangkan yaitu lembar observasi keterlaksanaan pembelajaran dan tes hasil kemampuan pemahaman konsep pretest dan posttest. Instrumen telah divalidasi oleh dua ahli.

Dua data yang diperoleh yaitu data observasi keterlaksanaan dan tes hasil kemampuan pemahaman konsep. Data observasi menggunakan lembar observasi. Lembar observasi diisi oleh dua orang observer, dan rata-ratanya dihitung untuk setiap pertemuan. Rata-rata setiap pertemuan kemudian dikategorikan sesuai Tabel 1.

TABEL 1. Konversi Nilai Tingkat Keterlaksanaan Model Pembelajaran dalam Data Ordinal

\begin{tabular}{cc}
\hline Skor Rata-rata & Kategori \\
\hline $1,0-1,4$ & Tidak Terlaksana \\
$1,5-2,4$ & Kurang Terlaksana \\
$2,5-3,4$ & Cukup Terlaksana \\
$3,5-4,0$ & Terlaksana Dengan Baik \\
\hline
\end{tabular}


Data yang kedua yaitu data tes hasil kemampuan pemahaman konsep. Data ini selanjutnya dianalisis secara deskriptif, yakni dengan menghitung rata-rata, median, rentang skor, dan variansi. Data yang dianalisis kemudian dikategorikan sesuai Tabel 2.

TABEL 2. Pedoman Pengkategorian Pemahaman Konsep

\begin{tabular}{|c|c|c|c|}
\hline \multirow{6}{*}{$\begin{array}{l}\text { Setelah data } \\
\text { yang diperoleh dari } \\
\text { dianalisis untuk } \\
\text { peningkatan hasil p }\end{array}$} & Interval Nilai & Kategori & \multirow{6}{*}{$\begin{array}{r}\text { dikategorikan, data } \\
\text { pretest dan posttest } \\
\text { mengetahui }\end{array}$} \\
\hline & $90-100$ & Sangat Tinggi & \\
\hline & $80-89$ & Tinggi & \\
\hline & $65-79$ & Sedang & \\
\hline & $55-64$ & Rendah & \\
\hline & $0-54$ & Sangat Rendah & \\
\hline
\end{tabular}

$$
N-\text { gain }=\frac{\text { Skor posttes }- \text { Skor pretest }}{\text { SMI }- \text { Skor pretest }}
$$

Keterangan :

$N-$ gain $\quad=$ Gain ternormalisasi

SMI = Skor Maksimal Ideal

Selanjutnya, data gain ternormalisasi di kategorikan sesuai Tabel 3.

TABEL 3. Kriteria Nilai $N$-gain

\begin{tabular}{cc}
\hline Interval & Kategori \\
\hline$N-$ gain $\geq 0,70$ & Tinggi \\
$0,30<N-$ gain $<0,70$ & Sedang \\
$N-$ gain $<0,30$ & Rendah \\
\hline
\end{tabular}

Analisis statistik inferensial dalam penelitian ini bertujuan untuk menguji hipotesis penelitian. Hipotesis dalam penelitian ini, yaitu terdapat perbedaan signifikan antara peningkatan pemahaman konsep matematika siswa yang diajar dengan metode Mind Mapping dan metode Guided Note Taking. Setelah di peroleh data yang diperlukan dalam penelitian dan dinyatakan berdistribusi normal dan homogen, maka dilakukan uji hipotesis yang diajukan dengan menggunakan statistik uji t (independent sampel t-test) digunakan bantuan software PSPP. Metode analisis yang digunakan dalam penelitian ini adalah analisis kuantitatif dengan taraf signifikansi $5 \%$.

\section{HASIL DAN PEMBAHASAN}

Terdapat dua kelas dalam penelitian ini, yaitu kelas eksperimen 1 yang diajar dengan metode Mind Mapping dan kelas eksperimen 2 yang diajar dengan metode Guided Note Taking. Deskripsi Hasil Observasi Keterlaksanaan Pembelajaran dapat dilihat pada Tabel 4.

TABEL 4. Observasi Keterlaksanaan Metode Mind Mapping

\begin{tabular}{llllll}
\hline \multirow{2}{*}{ Pertemuan } & \multicolumn{2}{l}{ Kegiatan Pembelajaran } & Rata- & \multirow{2}{*}{ Kategori } \\
\cline { 2 - 4 } & Pendahuluan & Inti & Penutup & rata & \\
\hline I & 3,38 & 3,7 & 3,6 & 3,56 & Terlaksana dengan baik \\
II & 3,51 & 3,8 & 3,7 & 3,67 & Terlaksana dengan baik \\
III & 4 & 4 & 4 & 4 & Terlaksana dengan baik \\
\hline Rata- Rata & 3,63 & 3,83 & 3,76 & 3,74 & Terlaksana dengan baik \\
\hline
\end{tabular}

Tabel 4 menunjukkan bahwa untuk skor rata-rata semua pertemuan yaitu 3,74, dan dikatakan bahwa terlaksana dengan baik. Selain itu dapat dilihat pada pertemuan I dan II rata-rata skor 
tidak mencapai 4, hal ini karena pengajar masih dalam tahap penyesuaian dengan kondisi pembelajaran di kelas, sedangkan pada pertemuan III terlihat bahwa skor rata-ratanya 4, hal ini menunjukkan bahwa pengajar telah lebih paham bagaimana menjalankan setiap langkah pembelajaran pada metode Mind Mapping.

TABEL 5. Observasi Keterlaksanaan Metode Guided Note Taking

\begin{tabular}{llllll}
\hline \multirow{2}{*}{ Pertemuan } & \multicolumn{2}{l}{ Kegiatan Pembelajaran } & Rata- & \multirow{2}{*}{ Kategori } \\
\cline { 2 - 4 } & Pendahuluan & Inti & Penutup & rata & \\
\hline I & 4 & 3,75 & 3,8 & 3,85 & Terlaksana dengan baik \\
II & 4 & 3,6 & 3,5 & 3,7 & Terlaksana dengan baik \\
III & 4 & 4 & 4 & 4 & Terlaksana dengan baik \\
\hline Rata- Rata & 4 & 3,78 & 3,76 & 3,85 & Terlaksana dengan baik \\
\hline
\end{tabular}

Tabel 5 menunjukkan bahwa untuk skor rata-rata semua pertemuan yaitu 3,85, dan dikatakan bahwa terlaksana dengan baik. Selain itu dapat dilihat pada pertemuan I dan II rata-rata skor tidak mencapai 4, hal ini karena pengajar masih dalam tahap penyesuaian dengan kondisi pembelajaran di kelas, sedangkan pada pertemuan III terlihat bahwa skor rata-ratanya 4, hal ini menunjukkan bahwa pengajar telah lebih paham bagaimana menjalankan setiap langkah pembelajaran pada metode Guided Note Taking.

\section{Hasil Pemahaman Konsep Matematika Siswa}

TABEL 6. Data Statistik Pretest

\begin{tabular}{lcc}
\hline \multicolumn{1}{c}{ Statistik } & Mind Mapping & Guided Note Taking \\
\hline Ukuran Sampel & 17 & 16 \\
Skor Ideal & 100 & 100 \\
Skor Tertinggi & 56 & 60 \\
Skor Terendah & 6 & 12 \\
Rentang Skor & 50 & 48 \\
Rata-Rata & 22,235 & 27,75 \\
Median & 20 & 24 \\
Standar Deviasi & 12,804 & 15,541 \\
Variansi & 163,941 & 241,533 \\
\hline
\end{tabular}

Tabel 6 menunjukkan bahwa perbandingan rata-rata pemahaman konsep kedua metode tidak memiliki perbedaan yang berarti, hal ini bisa dilihat dari selisih rata-rata yang rendah, yakni 5,52. Begitu juga dengan median, rentang skor, dan standar deviasi masing-masing metode, tidak memiliki selisih yang tinggi. Ini menunjukan bahwa sampel merupakan kelas yang homogen,.

TABEL 7. Data Statistik Posttest

\begin{tabular}{lcc}
\hline \multicolumn{1}{c}{ Statistik } & Mind Mapping & Guided Note Taking \\
\hline Ukuran Sampel & 17 & 16 \\
Skor Ideal & 100 & 100 \\
Skor Tertinggi & 88 & 84 \\
Skor Terendah & 28 & 18 \\
Rentang Skor & 60 & 66 \\
Rata-Rata & 63,529 & 47,625 \\
Median & 76 & 38 \\
Standar Deviasi & 22,523 & 21,728 \\
Variansi & 507,265 & 472,117 \\
\hline
\end{tabular}

Tabel 7 menunjukkan bahwa perbandingan rata-rata pemahaman konsep kedua metode memiliki selisih yang cukup tinggi, yakni 15,9. Begitu juga nilai median kedua metode yang 
memiliki selisih 38. Statistik ini menunjukkan bahwa metode Mind Mapping lebih memiliki pengaruh yang besar dalam meningkatkan pemahaman konsep siswa dibandingkan metode Guided Note Taking.

Setelah membandingkan skor pemahaman konsep dari data posttest kedua metode tersebut. Selanjutnya skor posttest dari kedua metode dikategorikan pada tabel 8 .

TABEL 8. Distribusi Frekuensi Nilai Pemahaman Konsep Matematika Siswa

\begin{tabular}{cccccc}
\hline \multirow{2}{*}{$\begin{array}{c}\text { Rentang } \\
\text { Nilai }\end{array}$} & \multirow{2}{*}{ Kategori } & $\begin{array}{c}\text { Mind } \\
\text { Mapping }\end{array}$ & $\begin{array}{c}\text { Guided Note } \\
\text { Taking }\end{array}$ & $\begin{array}{c}\text { Mind } \\
\text { Mapping }\end{array}$ & $\begin{array}{c}\text { Guided Note } \\
\text { Taking }\end{array}$ \\
\hline $90-100$ & Sangat Tinggi & 0 & 0 & $0 \%$ & $0 \%$ \\
$80-89$ & Tinggi & 7 & 2 & $41,17 \%$ & $12,5 \%$ \\
$65-79$ & Sedang & 2 & 3 & $11,76 \%$ & $18,75 \%$ \\
$55-64$ & Rendah & 0 & 0 & $0 \%$ & $0 \%$ \\
$0-54$ & Sangat Rendah & 8 & 11 & $47,06 \%$ & $68,75 \%$ \\
\multicolumn{2}{c}{ Jumlah } & 17 & 16 & $100 \%$ & $100 \%$ \\
\hline
\end{tabular}

Tabel 8 menunjukkan bahwa pada kedua metode tidak terdapat siswa yang berada pada kategori rendah dan sangat tinggi. Hal ini karena banyak siswa yang masih menyesuaikan diri dengan kedua metode ini, walaupun begitu metode ini sudah berhasil meningkatkan pemahaman konsep matematika siswa, jika ditinjau dari peningkatan skor pemahaman konsep kedua metode tersebut. Peningkatan skor pemahaman konsep dapat dilihat pada tabel 9.

TABEL 9. Data Statistik Peningkatan Pemahaman Konsep Matematika Siswa

\begin{tabular}{lcc}
\hline \multicolumn{1}{c}{ Statistik } & Mind Mapping & Guided Note Taking \\
\hline Ukuran Sampel & 17 & 16 \\
Skor Ideal & 100 & 100 \\
Skor Tertinggi & 0,84 & 0,72 \\
Skor Terendah & 0,03 & 0,03 \\
Rentang Skor & 0,81 & 0,70 \\
Rata-Rata & 0,52 & 0,31 \\
Median & 0,68 & 0,25 \\
Standar Deviasi & 0,30 & 0,19 \\
Variansi & 0,09 & 0,04 \\
\hline
\end{tabular}

Tabel 9 menunjukkan bahwa hasil n-gain untuk skor rata-rata pemahaman konsep metode Mind Mapping lebih tinggi dibandingkan hasil n-gain untuk skor rata-rata pemahaman konsep metode Guided Note Taking. Begitu juga jika kita lihat secara keseluruhan hasil n-gain dari metode Mind Mapping seperti rentang skor, median, standar deviasi, dll lebih tinggi dibandingkan metode Guided Note Taking. Ini menunjukkan bahwa peningkatan pemahaman konsep metode Mind Mapping lebih tinggi dari peningkatan pemahaman konsep metode Guided Note Taking.

Selanjutnya peningkatan hasil pemahaman konsep matematika siswa pada kedua metode dikategorikan pada tabel 10 .

TABEL 10. Kategori Gain Ternormalisasi

\begin{tabular}{ccccccc}
\hline \multirow{2}{*}{ Interval } & \multicolumn{2}{c}{ Jumlah siswa } & \multicolumn{2}{c}{ Persentase } & \multicolumn{2}{c}{ Kategori } \\
\cline { 2 - 7 } & $\begin{array}{c}\text { Mind } \\
\text { Mapping }\end{array}$ & $\begin{array}{c}\text { Guided } \\
\text { Note } \\
\text { Taking }\end{array}$ & $\begin{array}{c}\text { Mind } \\
\text { Mapping }\end{array}$ & $\begin{array}{c}\text { Guided } \\
\text { Note } \\
\text { Taking }\end{array}$ & $\begin{array}{c}\text { Mind } \\
\text { Mapping }\end{array}$ & $\begin{array}{c}\text { Guided } \\
\text { Note } \\
\text { Taking }\end{array}$ \\
\hline$N-$ gain $\geq 0.70$ & 8 & 1 & $47,05 \%$ & $6,25 \%$ & Tinggi & Tinggi \\
$0.30 \leq N-$ gain $<0.70$ & 4 & 5 & $23,53 \%$ & $31,25 \%$ & Sedang & Sedang \\
$N-$ gain $<0.30$ & 5 & 10 & $29,41 \%$ & $62,5 \%$ & Rendah & Rendah \\
\hline
\end{tabular}


Tabel 10 menunjukkan bahwa peningkatan skor pemahaman konsep siswa yang berada pada kategori tinggi lebih banyak pada kelas yang diajar metode Mind Mapping, yaitu sebanyak 8 siswa, dibandingkan dengan kelas yang diajar metode Guided Note Taking yang hanya sebanyak 1 siswa.

Skor rata-rata gain ternormalisasi untuk kelas yang diajar dengan metode Mind Mapping yang disajikan pada table 9 adalah 0,52, ini menunjukkan bahwa peningkatan pemahaman konsep matematika siswa pada metode Mind Mapping berada pada kategori sedang. Sedangkan untuk metode Guided Note Taking memiliki skor rata-rata 0,31, ini menunjukkan bahwa peningkatan pemahaman konsep matematika siswa pada metode Mind Mapping berada pada kategori sedang.

\section{Uji Hipotesis}

Sebelum melakukan uji hipotesis, terlebih dahulu dilakukan uji prasyarat sebagai acuan untuk menentukkan uji statistik yang akan digunakan dalam menguji hipotesis, uji prasyarat yang dimaksud dalam penelitian ini adalah uji normalitas dan uji homogenitas. Kriteria pengujian uji normalitas adalah data terdistribusi normal jika $p$-value $>\alpha=0,05$. Kriteria pengujian uji homogenitas adalah variansi kedua sampel sama apabila $p-$ value $>\alpha=0,05$.

Hasil uji normalitas dapat dilihat pada Tabel 11.

TABEL 11. Analisis Uji Normalitas

\begin{tabular}{lll}
\hline & Nilai Mind Mapping & Nilai Guided Note Taking \\
\hline Asymp. Sig. (2-tailed) &, 284 &, 347 \\
\hline
\end{tabular}

Tabel 11 menunjukan bahwa untuk data pemahaman konsep matematika siswa pada kelas yang diajar metode Mind Mapping, diperoleh $p$-value $=0,284$. Karena $p$-value $=0,284>$ $\alpha=0,05$, maka dapat disimpulkan bahwa data pemahaman konsep matematika siswa pada kelompok eksperimen 1 terdistribusi normal. Untuk data pemahaman konsep matematika siswa pada kelompok yang diajar metode Guided Note Taking, diperoleh $p-$ value $=0,347$. Karena $p$-value $=0,347>\alpha=0,05$, maka dapat disimpulkan bahwa data pemahaman konsep matematika siswa pada kelompok eksperimen 2 terdistribusi normal.

Hasil uji homogenitas dapat dilihat pada Tabel 12.

TABEL 12. Analisis Uji Homogenitas

\begin{tabular}{lc}
\hline & Sig. \\
\hline $\begin{array}{l}\text { Nilai Mind Mapping dan } \\
\text { Guided Note Taking }\end{array}$ &, 415 \\
\hline
\end{tabular}

Tabel 12 menunjukkan bahwa untuk uji homogenitas diperoleh $p-$ value $=0,415$. Karena $p$-value $=0,415>\alpha=0,05$, maka dapat disimpulkan bahwa variansi data pemahaman konsep matematika siswa dari kedua kelompok eksperimen adalah sama atau homogen.

Karena kedua prasyarat terpenuhi maka dilakukan uji hipotesis. Uji Hipotesis dapat dilihat pada Tabel 13.

TABEL 13. Analisis uji $-\mathrm{t}$

\begin{tabular}{llll}
\hline & & Sig. & Sig. (2-tailed) \\
\hline Gain ternormalisasi & $\begin{array}{l}\text { Equal variances assumed } \\
\text { Equal variances not asumed }\end{array}$ &, 006 &, 020 \\
& &, 019 \\
\hline
\end{tabular}

Tabel 13 menunjukkan bahwa untuk skor rata-rata gain ternormalisasi yang diajar dengan metode Mind Mapping dan metode Guided Note Taking, diperoleh $\mathrm{p}$ - value = 0,019. Jadi $\mathrm{p}-$ 
value $=0,019<\alpha=0,05$ yang berarti bahwa $\mathrm{H}_{0}$ ditolak dan $\mathrm{H}_{1}$ diterima. Ditolaknya $\mathrm{H}_{0}$ menunjukkan bahwa terdapat perbedaan signifikan antara peningkatan pemahaman konsep matematika siswa yang diajar dengan menggunakan metode Mind Mapping dan metode Guided Note Taking.

Pembahasan

Berdasarkan hasil analisis deskriptif, dapat disimpulkan bahwa penerapan metode pembelajaran Mind Mapping dan metode pembelajaran Guided Note Taking sama-sama mampu meningkatkan pemahaman konsep matematika siswa. Sehingga, kedua metode ini cocok diterapkan dalam pembelajaran matematika pada siswa kelas VIII. Tentunya, dengan mempertimbangkan kelebihan dan kekurangan masing-masing metode pembelajaran ini. Hal ini sejalan dengan hasil penelitian Utami (2016) tentang penerapan metode Mind Mapping untuk meningkatkan kemampuan pemahaman konsep matematis siswa. Penelitian ini menunjukkan bahwa metode Mind Mapping mampu meningkatkan kemampuan pemahaman konsep matematis siswa dibandingkan menggunakan metode pembelajaran konvensional.. Oleh karena itu, pembelajaran dengan metode Mind Mapping akan menuntun siswa dalam menguasai dan memahami konsep materi yang dipelajari. Begitupula sejalan dengan apa yang dikemukakan oleh (Herdin, 2017) bahwa Mind Map membantu kita untuk memetakan apa yang kita pikirkan, apa yang kita ingin ingat dengan baik.

Sejalan juga sebagaimana hasil penelitian yang dilakukan oleh Sulistia (2012) tentang penerapan metode pembelajaran Guided Note Taking untuk meningkatkan pemahaman konsep matematika, hasilnya menunjukkan bahwa terjadi peningkatan pemahaman konsep matematika siswa kelas IX pada pokok bahasan kesebangunan melalui penerapan metode pembelajaran Guided Note Taking, karena metode ini memfasilitasi siswa berperan aktif dalam belajar dengan menggunakan Handout.

Walaupun metode Mind Mapping dan metode Guided Note Taking sama-sama mampu meningkatkan pemahaman konsep matematika siswa, namun berdasarkan sampel yang diambil, uji hipotesis menunjukkan terdapat perbedaan signifikan antara peningkatan pemahaman konsep matematika siswa yang diajar dengan metode Mind Mapping dan metode Guided Note Taking.

\section{KESIMPULAN}

Tujuan penelitian ini adalah untuk mengetahui ada atau tidaknya peningkatan pemahaman konsep matematika siswa yang diajar dengan metode Mind Mapping dan metode Guided Note Taking pada kelas VIII. Hasilnya menunjukkan bahwa terdapat perbedaaan signifikan antara peningkatan pemahaman konsep matematika siswa yang diajar dengan metode Mind Mapping dan metode Guided Note Taking pada kelas VIII. Secara deskriptif, skor rata-rata gain ternormalisasi pemahaman konsep matematika siswa yang diajar dengan menggunakan metode Mind Mapping lebih tinggi dari skor rata-rata gain ternormalisasi pemahaman konsep matematika siswa yang diajar dengan menggunakan metode Guided Note Taking.

Penelitian ini hanya membandingkan hasil pemahaman konsep matematika saja. Terdapat beberapa hal lain yang dapat diteliti terkait metode pembelajaran Mind Mapping dan metode pembelajaran Guided Note Taking. Hal lain yang dapat diteliti terkait metode Mind Mapping dan metode Guided Note Taking diantaranya yaitu membandingkan tingkat aktivitas siswa, motivasi siswa dalam mengikuti pembelajaran, atau hal-hal menarik lainnya.

\section{DAFTAR PUSTAKA}

Ambarwatik. (2012). Metode Pembelajaran Guided Note Taking. Tersedia: http://masalahpendidikan-di-negaraku.blogspot.com/2012/07/metode- pembelajaran-guided-notetaking.html, Diakses tanggal 9 Desember 2018. 
Buzan, T. (2012). Buku Pintar Mind Map. Jakarta: Gramedia.

Departemen Pendidikan Nasional. (2003). Kamus Bahasa Indonesia. Jakarta: Pusat Bahasa.

Herdin, T.L.I. (2017). 7 Rahasia Mind Map Membuat Anak Genius. Jakarta: PT Elex Media Komputindo.

Heryani, Y., \& Rustina, R. (2016). Efektivitas Penerapan Model Pembelajaran Creative Problem Solving (CPS) Terhadap Peningkatan Kemampuan Pemecahan Masalah Matematika Mahasiswa. Jurnal Siliwangi, 4(1). 26-31

Munajah, A. (2015). Efektivitas Pembelajaran Matematika melalui Metode Guided Note Taking pada Siswa Kelas VIII6 Smp Negeri 16 Makassar. (Skripsi). Jurusan Matematika UNISMUH, Makassar.

Nurlina. (2014). Evektivitas Pembelajaran Quantum dengan Menggunakan Teknik Mind Mapping dalam Pembelajaran Matematika. (Skripsi). Jurusan Matematika UNM, Makassar.

Silberman, M. L. (1996). Active Learning: 101 Strategi Pembelajaran Aktif. Yogyakata: Pustaka Insan madani

Suherman, E. (2003). Strategi Pembelajaran Kontemporer. Bandung: PT Remaja Rosdakarya

Sulistia, R. (2012). Penerapan Metode Pembelajaran Guided Note Taking untuk Meningkatkan Pemahaman Konsep Matematika di Madrasah Tsanawiyah Negeri Kampar Kecamatan Kampar Kabupaten Kampar. (Skripsi). UIN Sultan Syarif Kasim Riau, Pekanbaru.

Suprijono, A. (2014). Cooperatif Learning: Teori dan Aplikasi PAIKEM. Yogyakarta: Pustaka Pelajar.

Utami, D. S.( 2016). Penerapan Metode Mind Mapping untuk Meningkatkan Kemampuan Pemahaman Konsep Matematis Siswa. (Skripsi). Fakultas Keguruan dan Ilmu Pendidikan Universitas Lampung, Bandar Lampung. 